\title{
INFLUENCE OF DOSAGE ON RETENTION IN PATIENTS METHADONE MAINTENANCE THERAPY PROGRAM FOR MAINTENANCE PHASE OF H. ADAM MALIK MEDAN CENTRAL GENERAL HOSPITAL
}

\author{
ROBIATUN RAMBE*, URIP HARAHAP, CITRA JULITA TARIGAN \\ Department of Pharmacology, Faculty of Pharmacy, University of Sumatera Utara, Medan, Indonesia. \\ Email: Robiatunrambe1990@gmail.com
}

Received: 12 January 2018, Revised and Accepted: 21 April 2018

ABSTRACT

Objective: This study aims to see the effect of methadone dose on patient retention in following the program.

Materials and Methods: This study is a clinical study with cross-sectional study design. Data obtained from the patient's medical record and patient's primary data. The study was conducted at Methadone Clinic of H.Adam Malik Hospital Medan.

Results: The number of research samples is injecting drug users who follow PTRM as many as 39 people. From a study of 39 patients, the percentage of male patients (100\%) was obtained; age between 25 and 35 years $(64.1 \%)$; junior high school education equal to $84.6 \%$; already married 46.2\%; already working 69.2\%; and the distance of the average residence with the clinic is $16.93 \mathrm{~km}$. The results showed that the smallest maintenance dose of maintenance phase was $2 \mathrm{mg}$; the largest maintenance dose in the maintenance phase was 165 mg; the mean maintenance stage dose of $62.35 \mathrm{mg}$ with a retention value $>2$ years or more ( $>730$ days) was $79.5 \%$.

Conclusion: There was a significant effect on retention which is the biggest maintenance dose with $\mathrm{p}=0.04$ value and take home dose with $\mathrm{p}=0.027$. Percentage of drug use and other substances that is benzodiazepines (BZO) (64,1\%); amphetamines (AMP) (38.5\%); methamphetamine (MET) (20.5\%); and THC (20.5\%). There was no significant effect between the use of other substance to retention with p value of BZO (0.389); p AMP (0.360); p MET (0.195); and p THC (0.470). It can be concluded that the greater the dose of methadone has an effect on its retention.

Keywords: Methadone, Methadone maintenance therapy, Retention.

(C) 2018 The Authors. Published by Innovare Academic Sciences Pvt Ltd. This is an open access article under the CC BY license (http://creativecommons. org/licenses/by/4. 0/) DOI: http://dx.doi.org/10.22159/ajpcr.2018.v11i8.24743

\section{INTRODUCTION}

Significant problems of global and inexpensive problems are significant spikes in Asia, including Indonesia are symptoms of narcotics, alcohol, psychotropic, and other active substances and HIV/AIDS transmission. The number of drug use in Indonesia continues to increase until 2008 reached 3.6 million people [1].

Opiate addicts commonly use heroin, and most use unsafe injections, both in terms of equipment that tends to be used repeatedly and alternately, as well as injection sites on the body that are not generally cleaned first. As a result, it is very easy to get infections such as bone, joint, endocarditis, sepsis, soft-tissue, and tetanus infections, as well as other blood-transmitted viruses such as Hepatitis (B, C, and D) and HIV [2].

Mortality rates of heroin use in the range of $1-2 \%$ per year due to overdose, drug-induced disease, and death from violence [3]. Premature deaths due to criminal problems to support heroin use habits, dose ambiguity, purity, and even heroin identity are used [4].

To reduce the adverse effects of opiate use by injection, harm reduction is required. One approach to harm reduction is a maintenance therapy program by providing metadona in liquid preparations, known as metadona Maintenance Therapy Program (PTRM) [2].

PTRM is already proven to help reduce opiate dependence. Unfortunately, there is a new problem that disrupts the success of this program, the drop out (DO) of methadone therapy that will result in the patient's desire to return again to consume heroin. In addition, patients will return at risk of contracting HIV and AIDS diseases. According to the 2006
MOH patients DOs ranged from 40 to 50\%. From research conducted by Dianawati in 2014 at 5 community health clinic in Jakarta, drop outpatient is high enough that is $18.6 \%-55.8 \%$. Retention or duration of patients on therapy is one of the indicators for this program [5]. Retention rate (retention rate) can be used to measure the success of the program. Research conducted by Liu et al., 2008 found retention rate of patients on methadone therapy in Guizhou China by $68.8 \%$ in 6 months of treatment and $57.4 \%$ in 12 months of treatment [6]. The retention rate in Malaysia is only about $54.69 \%$ in 6 months of treatment [7]. While the Sarasvita et al. study showed that retention rate of methadone therapy patients in Indonesia, in general, was $74.2 \%$ (3 months of therapy) and $61.3 \%$ (6 months of therapy) [8].

Research conducted by Huissod et al. [9] and Bao et al., [10] showed an influence between doses with retention of methadone therapy patients. Research Liu et al. [6] and Dilla et al. also showed an effect between doses with patient retention in methadone therapy [11].

Research in hospital drug addiction Jakarta related to retention predictors for 1 year or more in various variables, i.e. age, methadone dose, sex, education, residence, occupation, and marital status. It was found that dosage and age were predictors of 1 year or more of retention in methadone maintenance therapy (MMT) [2]. Based on the problem, this research is intended to examine the effect between dose and retention and has never been done in RSUP H. Adam Malik Medan.

\section{METHODS}

Research design

The data were collected prospectively for patients who participated in the MMT program at Adam Malik General Hospital in Medan. The data 
obtained were then collected as one population considering the focus of this study were the dosage and retention given to opioid-dependent patients receiving MMT. The effect of various maintenance phase doses with MMT retention was further investigated.

\section{Population and sample research}

The population in this study was all outpatients who underwent MMT Haji Adam Malik General Hospital Medan. The samples in this study were all patients of MMT programs that met the inclusion criteria and were observed.

\section{Inclusion criteria}

The following criteria were included in this study:

1. Patients who are opiate addicts who undergo MMT.

2. Patients who are opiate addicts who receive MMT for the $1^{\text {st }}$ time at Haji Adam Malik General Hospital Medan.

3. The patient is in therapy for more than 6 weeks (42 days).

4. Patients of methadone therapy programs who receive antiretroviral therapy.

\section{Independent variables}

a. The smallest mud dose: The smallest dose of methadone the patient receives in the maintenance phase.

b. Largest dose of maintenance: The largest methadone maintenance dose the patient receives in the maintenance phase.

c. Average dose of maintenance: The average methadone dose the patient receives.

\section{Dependent variables retention}

The duration of the participants in the therapy was calculated from the $1^{\text {st }}$ day of the patient getting methadone up to the therapy or until the end of the data capture limit.

\section{Confounding variables gender}

It is the patient's gender who follows the MMT program listed in the patient's medical colleague.

\section{Patient age}

Is the age of the patient based on the data listed in the medical record.

\section{Education}

Is the last educational level successfully completed patients based on the data listed in the medical record.

Work

It is the main activity that the patient performs daily based on the data listed in the medical record.

\section{Marital status}

Is the marital status of patients according to the law of religion and the law of the state based on the data contained in the medical record.

\section{Race/ethnicity}

Is a race/race in patients who follow MMT program.

\section{Distance of residence}

It is the patient's place of residence based on the data listed in the medical record.

\section{The history of missed doses}

Is the record of the absence of patients in the MMT every day for no reason.

\section{Urine examination}

Urine drug screen is a urine test an objective examination to detect the presence of deep opiate metabolite urine. It is confirmed that the urine examined is the urine of the patient concerned.

\section{Statistical analysis}

The data of the research were then analyzed statistically using SPSS 17 verification with descriptive analysis and correlation analysis. The influence of the variables was analyzed using Chi-square tests analysis. A two-way test with $\mathrm{p}<0.05$ is considered meaningful.

\section{RESULTS AND DISCUSSION}

The study was conducted on opioid dependency patients who were treated at the Metadon outpatient unit at RSUP H. Adam Malik Medan. Overall, 39 patients were included in the inclusion criteria. Of the total daily methadone patients were $19(48.7 \%)$ and 20 people $(51.3 \%)$ of take-home dose (THD). There are 7 patients who follow the MMT also using HCV anti-viral drugs.

\section{Patient characteristics gender}

All patients in the study consisted of 39 men (100\%). Research lee et al. in Taiwan male opioid dependency ratio is greater than women of $82.9 \%$ and $17.1 \%$ [12]. This is not much different from Aprylia's study that almost all patients participate in a male-pattern MMT program $(94.7 \%)$.

\section{Patient age}

The patient age in the $25-35$ study counted 25 people $(64.1 \%)$ and age over 35 years 14 people (35.9\%) with an average score of $34.9( \pm 4.4)$. A 2016 study in Iran of 1396 patients whose mean age of patients attended a 37-year-old MMT [13]. In another study conducted by Sarasvita et al., it was stated that the average age of patients taking MMT courses over 27 years.

\section{Education}

Patients who participated in MMT at RSUP H. Adam Malik Medan were 2 persons (5.1\%) with elementary education, 1 person $(2.6 \%)$ with junior high school or equivalent, 33 people (84.6\%) had high school education or equal, and 3 people $(7.7 \%)$ educated undergraduate. This result is not much different from Pahlemy's research, 2010 that the highest percentage of patients whose education is high school or equivalent is $70.6 \%$ [4].

\section{Race/ethnicity}

The highest racial percentage in this study was in Batak tribe 17 people (43.6\%), Javanese 16 people (41.0\%) and Malay, Chinese and Padang tribes, respectively, 2 people $(5.1 \%)$.

\section{Marital Status}

The highest marital status was married 18 people (46.2\%), unmarried 14 people (35.9\%), and widower status as many as 7 people $(17.9 \%)$. Previous studies have found that opioid-dependent patients mostly have problems in the family resulting in a divorce process (widower) of $17.44 \%$ [14].

\section{Work}

The study stated that patients who participated in the dominant MMT program had worked at $69.2 \%$, not working at $30.8 \%$, unlike previous studies which found that the percentage of patients taking the majority methadone therapy program did not work 64.6\% [8], 61.63\% [15]. The above results show that patients taking methadone therapy programs are in stable, healthy and able to perform their activities well. Patients who are obedient to take medication methadone health can be protected from withdrawal symptoms and can work [16].

\section{Distance service place}

Distance service places affect the patient's compliance level in following the methadone maintenance program. The distance between patient's residence and service place is $16.93 \mathrm{Km}$. This considerable distance affects the patient's presence in each treatment process, thus affecting the outcomes of each patient's outcome. Research conducted Phallyka distance of residence around $4 \mathrm{~km}$ from the clinic where the service will increase the value of retention [17] 
Description of methadone dose of stroke phase in patient MMT program

The average dosage received by patients taking MMT program for 39 people was $62.35 \mathrm{mg}$, while the smallest maintenance value was $2 \mathrm{mg}$ and the biggest maintenance dose was $165 \mathrm{mg}$. Descriptive methadone dose of the maintenance phase is shown in Table 1.

\section{Influence of methadone dose with retention}

The various factors that influence the patient surviving in a MMT program are the dose factors [18]. High retention is influenced by the higher methadone dose given to patients on methadone therapy [17]. In this study, it was found that high doses $>60 \mathrm{mg} /$ day had a statistically significant retention effect of $\mathrm{p}=0.04$, this was consistent with the Phallyka study [17] that the methadone dose $>60 \mathrm{mg} /$ day had an effect meaningful with $\mathrm{p}=0.03$. Predictor variables in 1 year found that high dose effects and other drug abuse affected retention [18].

\section{Patient retention for MMT program}

The retention time of a total of 39 retention patients was $<730$ days as many as 8 people (20.5\%), and the retention percentage was 31 persons (79.5\%) with retention> 730 days. One indicator of the success of a MMT program is its high retention [19]. In the prevention of relapse of long-term therapy is the most effective strategy necessary to overcome opioid dependence [20]. Long-term methadone therapy showed more effective results than short-term therapy [21]. Research conducted by Zahar et al., comparison of pain response between opioid-dependent patients and opioid naive subjects MMT shows the overall mean difference of pain tolerance between opioid naive subjects compared to MMT patients [26]

\section{The influence of overdose dose of PTRM patient retention}

A total of 15 patients $(37.5 \%)$ had a missed dose of 1-2 consecutive days; only 1 person $(2.6 \%)$ had a missed dose of 3-4 days. The number of patients who had never missed a dose of 23 patients (59.0\%).

The effect of dose is missed when it is associated with the method of giving home dose take dosage then there is a significant influence on the value of $p=0.027$. This is in line with research conducted by Susilowati that the influence of dose take THD with patient retention and adherence in therapy and tended to stay longer in therapy [18]. Other findings also found that the doses administered by THD would increase retention rates [9].

\section{The effect of other substances on retention}

Research conducted by Khoubnasabjafari et al. monitoring drug concentrations dengan extraction and analysis of methadone in exhaled breath condensate using a validated liquid chromatography ultraviolet method [27]. From the study, it was found that the percentage of other substance use in patients of the largest MMT program was benzodiazepine group medicine as many as 25 patients $(64.1 \%)$, can be seen in Table 2 .

Research conducted by Lee et al. in Taiwan that the greatest percentage of patients taking the drug (other substances) simultaneously in a MMT program is a benzodiazepine-type drug [24]. Concurrent use of low to moderate doses of benzodiazepines (BZO) is still possible, but it is necessary to be aware of increased drowsiness and diminished psychomotor performance. The use of high-dose BZO is a risk factor for sudden death in patients receiving methadone therapy [25]. The use of methadone in conjunction with BZO can also increase the effects of sedation and respiratory depression and may increase opioid effects [25].

\section{CONCLUSION}

This study is: (a) The smallest maintenance dose of the maintenance phase $=2 \mathrm{mg}$; the largest maintenance dose of maintenance phase $=165 \mathrm{mg}$; and average maintenance dose of maintenance phase $=62.35 \mathrm{mg}$. (b) The largest retention value is 10 years of retention of the smallest 1 year
Table 1: Descriptive methadone dose of stages of maintenance

\begin{tabular}{llll}
\hline & Smallest creep & The biggest mud & Average \\
\hline Dosis $(\mathrm{Mg})$ & 2.00 & 165.00 & 62.35 \\
\hline
\end{tabular}

Table 2: Percentage of other substance use

\begin{tabular}{ll}
\hline Type of substance & Percentage \\
\hline AMP & 38.5 \\
MET & 20.5 \\
THC & 20.5 \\
MOP & 0 \\
BZO & 64.1 \\
\hline
\end{tabular}

AMP: Amphetamines, MET: Methamphetamine, THC: MOP: Morphine, BZO: Benzodiazepines

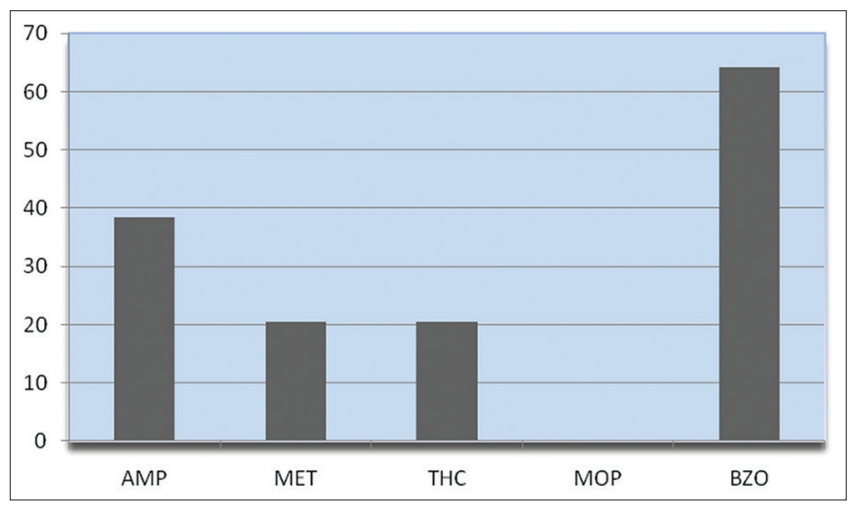

Figure 1: Graph of the use of other substances in PTRM patients

with an average retention rate of 4.7 years. Retention value $>2$ years or more $(>730$ days $)=(79.5 \%)$. (c) The largest maintenance dose showed a significant effect with the value of $p=0.04$. (d) Missed dose with retention in MMT 15 patients (37.5\%) had a missed dose of 1-2 consecutive days, there was a significant effect associated with a THD methadone method, meaningful with value $p=0.027$. (e) The use of drugs and other substances during MMT is amphetamine (AMP) BZO (64.1\%), AMP (38.5\%), methamphetamine (MET) (20.5\%) and THC $(20.5 \%)$. There was no significant effect between the use of other substances on retention with p=BZO (0.389), p=AMP (0.360), p=MET (0.195), and p=THC (0.470).

\section{AUTHOR'S CONTRIBUTION}

Urip Harahap, has a majorly role in the conducting the experiment in the laboratory and practise, analysis of obtained data and sincerely authored the article.

Julita Tarigan has provided the design, intellectual content, innovations, and protocol for conducting the experiment along with mentorship.

\section{CONFLICTS OF INTEREST}

We declare that there are no conflicts of interest.

\section{REFERENCES}

1. National Institute of Health/NIH. Principles of Drug Addiction Treatment A Research Based Guide. $2^{\text {nd }}$ ed. National Institute of Health/ NIH; 2009. Available from: http://www.drugabuse.gov/PDF/PODAT/PODAT.pdf.

2. Peraturan Menteri Kesehatan Republik Indonesia (PerMenKes RI) Nomor 57. Tentang Pedoman Penyelenggaraan Program Terapi Rumatan Metadon. Jakarta: Peraturan Menteri Kesehatan Republik Indonesia; 2013.

3. Association of Southeast Asian Nations(ASEAN)-USAID. Managing Opioid Dependence: Treatment and Carefor HIV Positive Injecting 
Drug Users. Jakarta: ASEAN Secretariat; 2007.

4. Helsy P. Hubungan Dosis dan Retensi Pada Terapi Rumatan Metadon Multiepisode DiRumah Sakit Ketergantungan Obat Jakarta Dan Rumah Sakit Umum Pusat Fatmawati. Jakarta: Universitas Indonesia; 2010.

5. Dianawati A. Faktor Faktor Yang Mempengaruhi Retensi Pasien Program Terapi Rumatan Metadon (PTRM) Pada Puskesmas Kecamatan Di Jakarta. Fakultas Kedokteran. Yogyakarta: Universitas Gadjah Mada; 2014.

6. Liu E, Liang T, Shen L, Zhong H, Wang B. Correlates of methadone client retention: A prospective cohort study in guizhou province, China. Int J Drug Policy 2009;20:304-8.

7. Mohamad N, Hidayah N, Musa N, Talib N, Ismail R. Better retention of Malaysian opiate dependents treated with high dose methadone in methadone maintenance therapy. Harm Reduct J 2010;7:30.

8. Sarasvita R. Treatment Retention In Methadone Maintenance Program In Indonesia: Toward Evidence-Informed Drug Policy. Thesis, University of Adelaide; 2009.

9. Huissod T, Rousson V, Arber FD. Methadone treatments in a swiss region, 2001-2008: A registry based analysis. BMC Psychiatry 2012:12:238

10. Bao YP, Liu Z. A meta-anaysis of retention in methadone maintenance by dose and dosing strategy. Am J Drug Alcohol Abuse 2009;35:28-33.

11. Dilla A, Ridwan A, Ansariadi. Relationship Between Behavioral Factors With Retention Of Patient Methadone Maintenance Treatment Program In Kassi-Kassi Health Center Bagian Epidemiologi Fakultas Kesehatan Masyarakat Universitas Hasanuddin; 2014

12. Lee FJ, Lo MS, Chang HY, Lee SY, Lu RB. Faktor associated eith retention in a methadone maintenence treatment program in heroindependent han Chinese In Taiwan. Neuropsychiatry 2017; 7:204-11.

13. Mahmood SF, Fateme, Hamid N, Mohsen R. Predictor of one years retention in methadone maintenence treatment (MMT) in Iran, Rafsanja. High Risk Behav Addict Iran.

14. Lee YH, Li HJ, Wu TL, Wu SJ, Yen FC, Tang PH. Survey of methadonedrug interaction among patients of methadone maintenence treatment program in Taiwan. Substance abuse treatment, prevention, and policy. Biomed Central 2012;7:11

15. Jiang H, Han Y, Du J, et al. Faktor associated with one year retention to methadone maintenence treatment program among patient with heroin dependence in China. Substance Abuse Treatment, Prevention and Policy.

16. Hanasah N. Pengaruh obat Antiretroviral Lini Pertama Terhadap Dosis
Metadon Pasien program terapi rumatan metadon di RSKO dan RSUP Fatmawati periode 2003-2009. Jakarta: FMIPA UI; 2010

17. Phallyka C. Propective Cohort Study of Factors Associated with Retention of Menthadone Maintenence Therapy Among Patient at the Center for Menta Haelth and Drug Dependence in Cambodia. Thesis Prsented to the Highger Degree Committe. Graduate of Ritsumeikan Asia Pacific University.

18. Susilowati I. Gambaran Dan Faktor Faktor Yang Berhubungan Dengan Retensi Pasien Program Terapi Rumatan Metadon (PTRM) Di Puskesmas Kecamatan Tebet. Jakarta: FKM. UI; 2013

19. Ward J, et al. An Evaluation of private methadone clinics. In: Methadone Maintenance Treatment and Othe Opioid Replacement Therapies. Amsterdam: Harwood academic publisher; 1998.

20. World Health Organization. WHO/UNDOC/UNAIDS Position Paper: Substitution Maintenance Therapy in the Management of Opioid Dependence and HIV/AIDS Prevention. Geneva: WHO; 2008. Sweetman SC, Blake PS, McGlashan JM, Neathercoat GC, Parsons AV.

21. Martindale: The Complete Drug Reference. $35^{\text {th }}$ ed., Vol. 02. London: Pharmaceutical Press; 2007.

22. Fathollahi SM, Torka F, Najmeddin N, Rezaeian M. Predictor of one year retention in methadone maintenence treatment (MMT) in Iran. Rafsanja. Zahedan Univ Med Sci 2016;5:

23. Eur JC, Hallinan R, Crettol S, Agho K, Attia J, Besson J, Croquette-Krokar $\mathrm{M}$, et al. Cannabis and benzodiazepines as determinants of methadone trough plasma concentration variability in maintenence treatment: A transnational study. Pharm and disposition. Eur J Clin Pharmacol 2009;65:1113-20.

24. Lee YH, Li HJ, Wu TL, Wu SJ, Yen FC, Tang PH. Survey of methadonedrug interaction among patients of methadone maintenence treatment program in Taiwan. Substance abuse treatment, prevention, and policy. Biomed Central 2012;7:11.

25. Baxter K. Stokley's Drug Interaction. $8^{\text {th }}$ ed. London: Pharmaucetical Press; 2008.

26. Zahar Z, Lee S, Ibrahim AM, Musa N, Azhar M, Yasin M, et al. Comparison of pain tolerance between opioid dependent patients on methadone maintenance therapy (MMT) and opioid naive individuals. J Pharm Pharm Sci 2016;19:127-36.

27. Khoubnasabjafari M, Ansarin K, Gharamaleki JV, Azar PV, Shayanfar A, Mohammadzadeh L, et al. Extraction and analysis of methadone in exhaled breath condensate using a validated LC-UV method. J Pharm Pharm Sci 2015;18:207-19. 